\title{
Study Resource Primary Indicator
}

National Cancer Institute

\section{Source}

National Cancer Institute. Study Resource Primary Indicator. NCI Thesaurus. Code C94138.

Specifies whether this is the main or principal study resource. 